\title{
List of maps and tables
}

\section{Maps}

1.1 The First World War in East Prussia. 25

4.1 The Eastern Front, 1914-17. 92

6.1 Austria-Hungary during the First World War. 132

8.1 Italy's refugees during the First World War. Source:

Ministero per le Terre Liberate, Censimento dei profughi di Guerra, Roma, 1919, pp. 218-19. 184

10.1 Location of refugees from four departments in France, September 1918.

11.1 Serbia during the First World War. 237

12.1 Bulgaria and its neighbours during the First World War. $\quad 261$

14.1 The Ottoman Empire during the First World War 306

\section{Tables}

6.1 Camps in Cisleithania during the First World War with more than 500 inmates. 